\title{
OPTIMASI PROSES PERAKITAN CAR STEREO DENGAN MENGGUNAKAN SISTEM MANUFAKTUR SELULAR
}

\author{
Dodi Mulyadi, Budhi M. Suyitno dan Susanto Sudiro \\ Jurusan Teknik Mesin, Fakultas Teknik, Universitas Pancasila, Jakarta \\ e-mail: dodi.mulya97@gmail.com
}

\begin{abstract}
Today's global market competition has spurred the producers of manufactured products to perform a variety of efficiency and continuous improvement for increasing the productivity of workers and reducing the cost of manufacture. Its aim is for helping companies to survive in the global competition. Thus, the companies can sell their products with more competitive price. Changing the conventional working system with better one - using a cellular manufacturing system - is one of the efficiency that can be done by the manufacturing companies. However the firm which had changed its conventional manual assembling system into mobile (cellular) assembling system resulted the improvement of workers knowledge from 3 up to 6 grade previously, it reduced 2 workers with the same number of work stations, increased the efficiency of assembling lines as much as 7.18\%, increased worker productivity as much as $14.28 \%$ with the same production capacity, reduced Not Right First Time / NRFT as much as 37.50\%, increased the Value Added Per Person / VAPP as much as 12.70\%, and raised the Floor Space Utilization / FSU as much as 3.17\%.
\end{abstract}

Keyword: Productivity, Assembling Line Efficiency, Manual Assembling System, Cellular Manufacturing System

\section{PENDAHULUAN}

Secara umum, proses perakitan produk-produk elektronik, termasuk juga proses perakitan car stereo, masih menggunakan cara-cara yang manual dan dikerjakan pada suatu lini perakitan konvensional. Pada lini perakitan konvensional ini, satu orang pekerja akan mengerjakan sejumlah pekerjaan tertentu pada satu stasiun kerja saja. Proses perakitan seperti ini memiliki banyak kelemahan yang sering dikeluhkan seperti tugas-tugas yang monoton sehingga dapat membosankan para pekerja karena pekerjaan yang diulang-ulang, kecepatan kerja yang harus dipertahankan sama ketika menggunakan konveyor sebagai pemindah barang, kualitas kerja yang rendah atau tingginya produk cacat, kerusakan salah satu peralatan kerja akan menyebabkan terhentinya pekerjaan secara total, produktivitas pekerja sangat sulit untuk ditingkatkan, semakin tingginya biaya seiring dengan kenaikan upah para pekerjanya, dan masalah-masalah lainnya. Pada akhirnya masalah-masalah tersebut akan berdampak pada tingginya biaya manufaktur dan harga akhir produk yang kurang kompetitif.

Untuk mengatasi kelemahan dan keluhan-keluhan di atas, ada beberapa sistem perakitan yang dapat dijadikan sebagai alternatif pengganti, misalnya dengan cara memberi cakupan pekerjaan yang lebih banyak bagi setiap pekerja yaitu dengan cara membentuk sistem perakitan selular stasiun tunggal, sistem perkaitan selular dengan sejumlah tim kerja, atau bahkan dengan cara otomasi proses perakitan.

Optimasi proses perakitan car stereo yang dimaksudkan dalam penelitian ini merupakan proses perakitan car stereo untuk tipe mecha less, dengan membentuk sistem perakitan selular dengan sejumlah tim kerja.

\section{Group Technology dan Sistem Manufaktur Selular}

Group Technology adalah sebuah filosofi sistem manufaktur dimana komponen-komponen yang serupa diidentifikasi dan dikelompokan untuk memperoleh keuntungan dari segi kemiripannya baik kemiripan dari desainnya maupun dari proses produksinya. Komponen yang serupa kemudian dikelompokan dalam suatu rumpun komponen (part families), dimana setiap komponen dalam rumpun tersebut mempunyai karaktersitik desain dan atau proses manufaktur yang mirip. Pengelompokan peralatan produksi ke dalam suatu sel dimana setiap sel mempunyai spesialisasi 
tertentu dalam memproduksi sebuah komponen yang serumpun disebut sebagai manufaktur selular [1].

Sistem manufaktur selular adalah suatu sistem manufaktur dimana seorang atau beberapa orang pekerja mengerjakan seluruh proses pekerjaan, sel ini biasanya dibentuk dengan tata ruang U. Tata ruang $U$ ini cocok digunakan ketika ada beberapa perbedaan dalam aliran benda kerja diantara beberapa komponen yang dibuat dalam sel tersebut. Hal ini juga memungkinkan para pekerja multifungsi dalam sel untuk dapat mudah berpindah dari satu mesin ke mesin lainnya. Selain itu, beberapa keuntungan tata ruang $U$ lainnya jika dapat meningkatkan kualitas, memudahkan pengontrolan work-in-process secara visual, investasi awal yang murah karena sel sangat sederhana dan tidak memerlukan conveyor, serta lebih fleksibel terhadap kenaikan permintaan produk (demand) yaitu dengan cara menambahkan sel lainnya [1]. Keuntungan tata ruang U lainnya adalah memudahkan pengontrolan kedatangan material yang akan diproses (incoming raw material) dan keluarnya produk jadi (outgoing finished product) [2].

Ada banyak manfaat dari sistem manufaktur selular untuk perusahaan jika diterapkan dengan benar. Diantaranya adalah proses menjadi lebih seimbang dan produktivitas meningkat karena lantai manufaktur telah direorganisasi dan telah diperbaiki. Pergerakan tiap produk atau komponen produk, waktu persiapan, dan waktu menunggu diantara tiap proses operasi dapat berkurang, sehingga dapat mengurangi waktu menganggur. Sistem manufaktur selular jika dikombinasi dengan lean manufacturing lainnya dan proses just-in-time, juga dapat membantu menghilangkan kelebihan stok barang dengan hanya memproduksi barang-barang ketika barang tersebut dibutuhkan. Sehingga hal ini akan menjadi penghematan biaya dan kontrol yang lebih baik dari operasi perusahaan [3].

Dalam sistem manufaktur selular, setiap pekerja cenderung lebih aktif dan mereka akan terus-menerus mencurahkan kemampuan mereka dalam mengatasi setiap masalah yang ada. Setiap pekerja pada suatu unit sel kerja merupakan orang yang paling paham dalam proses produksi sehingga cenderung dapat memunculkan ide-ide kreatif lain yang secara mandiri dapat menimbulkan perbaikan-perbaikan secara terus menerus. Bahkan sesama pekerja dalam sel lainnya, mereka cenderung akan bersaing secara sehat untuk memperbaiki prestasi kerja mereka masingmasing [3].

Sebuah perusahaan elektronik yang memproduksi relay dan switch untuk aplikasi industri telekomunikasi, industri sistem kontrol, otomotif dan aplikasi lainnya telah melakukan perubahan lini perakitan reguler menjadi lini perakitan selular. Perubahan dilakukan dengan cara merubah alur proses produksi, menambah atau mengurangi beban pekerjaan untuk setiap operator pada stasiun kerja sehingga beban pekerjaan menjadi lebih seimbang untuk setiap sel kerja yang dibentuk. Dengan perubahan ini perusahaan bisa mengurangi jumlah pekerja dari 13 orang menjadi 10 orang, menaikan tingkat produktivitas dari 43,28\% menjadi 65,64\% (atau meningkat sebesar 51,67\%), serta menurunkan tingkat inventori menjadi mendekati nol [4].

Perusahaan lain yang bergerak di bidang pembuatan pipa dengan berbagai macam ukuran pipa lebih dari 45 tipe dan melayani 9 pelanggan yang berbeda telah melakukan perubahan tata letak pabrik dengan menggunakan sistem manufaktur selular. Perubahan tata letak ini dilakukan dengan cara mengatur ulang tata letak mesin dan proses dengan menggunakan prinsip sistem manufaktur selular. Hasil dari perubahan tata letak ini dapat mengurangi luas lantai yang digunakan sebesar $20 \mathrm{~m}^{2}$, menghilangkan satu mesin pre-cutting (karena kebutuhan produk sudah dicukupi dengan mesin lainnya), mengurangi 1 orang pekerja untuk perpindahan material dan mengurangi 1 orang pekerja untuk mesin pre-cutting [2].

Perusahaan lainnya yang bergerak dalam pembuatan hose and tube untuk komponen air conditioning mobil telah melakukan perubahan sistem perakitan dari lini perakitan bergerak menjadi sel manufaktur. Perubahan proses perakitan ini dimulai dengan cara mengelompokan komponen yang serumpun (part-families), menentukan waktu pacu (takt-time), standarisasi proses dan pergerakan operator, serta mengecek ulang ketepatan waktu aktual proses perakitan sistem sel 
manufaktur terhadap waktu pacu. Jika terjadi ketidaksesuaian antara waktu pacu dengan aktual proses perakitan, maka dilakukan pengecekan ulang apakah hal ini disebabkan oleh keterlambatan operator atau karena keterlambatan mesin. Hasil dari perubahan sistem perakitan ini adalah luas lantai produksi yang digunakan berkurang dari $1500 \mathrm{ft}^{2}$ menjadi $320 \mathrm{ft}^{2}$, berkurangnya jumlah pekerja dari 18 orang menjadi 13 orang, menurunkan man-hour dari 170 jam menjadi 96 jam, menurunkan tingkat produk yang cacat dari 226 cacat/bulan menjadi 2,5 cacat/bulan, menurunkan tingkat ketidakhadiran para pekerja dari $4 \%$ menjadi $0 \%$, menurunkan work in process (wip) dari 150 wip menjadi 6 wip, serta menghilangkan konveyor [5].

\section{Lini Perakitan Manual}

Lini Perakitan Manual adalah suatu lini produksi yang terdiri dari beberapa stasiun kerja yang berurutan sesuai dengan proses pekerjaan yang harus dilakukan, dimana proses perakitannya dilakukan oleh manusia. Produk yang akan dirakit berpindah dari satu stasiun kerja ke stasiun berikutnya dalam suatu lini perakitan dengan sebuah sistem pemindahan produk, dan para pekerja di setiap stasiun kerjanya akan melakukan sejumlah pekerjaan yang merupakan sebagian pekerjaan dari sejumlah proses perakitan sebuah produk. Laju kecepatan produksi (production rate) dari suatu lini perakitan manual ini akan ditentukan oleh stasiun perakitan yang paling lambat [1].

Sistem pemindahan benda kerja dari suatu stasiun kerja ke stasiun kerja berikutnya dapat dibagi menjadi 2 (dua) sistem, yaitu sistem pemindahan secara manual dan sistem pemindahan secara mekanis. Dalam sistem pemindahan benda kerja secara manual, benda kerja akan dipindahkan ke stasiun berikutnya oleh pekerja itu sendiri. Sistem ini mempunyai kelemahan yaitu terjadinya starving dan bloking. Starving adalah situasi dimana seorang pekerja sudah menyelesaikan pekerjaannya akan tetapi benda kerja selanjutnya belum sampai ke stasiun tersebut. Sedangkan blocking adalah situasi dimana seorang pekerja sudah menyelesaikan pekerjaannya akan tetapi benda kerjanya tidak bisa dipindahkan ke stasiun berikutnya dikarenakan belum siapnya pekerja pada stasiun penerima [1].

Sebuah lini perakitan harus didesain untuk mencapai production rate yang sesuai dengan jumlah permintaan produk. Production rate dapat dihitung dengan cara membagi jumlah permintaan produk dengan jumlah waktu kerja [1].

$$
R p=\frac{D a}{\sum T}
$$

dimana

$R p \quad:$ production rate (unit/jam)

$\mathrm{Da}$ : jumlah permintaan produk dalam suatu periode (unit produk)

$\sum T$ : jumlah jam kerja dalam periode $D a$

Production rate ini kemudian harus dikonversi menjadi waktu siklus ideal, yang merupakan interval waktu pada suatu lini perakitan yang akan dioperasikan. Waktu siklus ideal yang diambil harus memperhitungkan waktu kerja efektif, dimana beberapa saat waktu kerja tidak dapat digunakan untuk bekerja yang disebabkan oleh adanya kerusakan pada peralatan, kekurangan komponen, masalah kualitas, masalah pekerja, dan masalah-masalah lainnya. Waktu efektif kerja ini dinamakan sebagai efisiensi lini. Sehingga waktu siklus ideal ditentukan sebagai berikut [1]:

$W s($ ideal $)=\frac{60 E}{R p}$

dimana

Ws : waktu siklus (menit/unit)

60 : konversi production rate dari jam menjadi menit 
E $\quad$ : efisiensi lini, untuk lini perakitan manual biasanya sekitar 0,9 sampai dengan 0,98

Waktu siklus ideal (Ws-ideal) ini kadang disebut juga sebagai takt-time (Ttakt). Takt berasal dari bahasa Jerman yang berarti irama atau langkah.

Untuk menentukan jumlah minimum pekerja secara teoritis pada sebuah lini perakitan manual dapat dihitung dengan cara:

$w \geq \frac{T w c}{W s}$

Dimana Twc adalah jumlah total waktu kerja yang diperlukan untuk menyelesaikan perakitan satu buah unit produk. Akan tetapi dalam prakteknya, jumlah pekerja minimum ini kemungkinan tidak bisa diterapkan karena dua hal yaitu repositioning losses, dimana beberapa saat waktu kerja akan hilang pada setiap stasiun kerja yang digunakan untuk menempatkan ulang benda kerja atau pekerja itu sendiri, sehingga waktu yang tersedia untuk menyelesaikan pekerjaan akan lebih sedikit dibandingkan dengan waktu siklus ideal; dan line balancing, dimana hampir tidak mungkin membagi waktu kerja yang sama untuk setiap stasiun kerja yang dibentuk, sehingga pada beberapa kasus hal ini akan menjadi penyebab meningkatnya jumlah pekerja [1].

Sistem perakitan selular stasiun tunggal terdiri dari hanya satu stasiun kerja saja dimana proses perakitan produk atau sub-perkaitan produk diselesaikan di satu stasiun kerja tersebut. Metode ini biasanya digunakan untuk proses perkaitan produk yang rumit dan diproduksi dalam jumlah yang relatif sedikit, bahkan kadan-kadang hanya satu unit saja. Stasiun kerja ini bisa menggunakan satu orang pekerja saja atau beberapa orang pekerja tergantung dari ukuran produk dan laju kecepatan produksi yang diminta. Contoh produk yang dirakit dalam stasiun kerja ini adalah mesin-mesin yang bersifat pesanan (tidak terdapat dipasaran dan hanya dibuat ketika ada pesanan), peralatan industri dan prototipe [1].

Sistem perakitan selular dengan sejumlah tim kerja dapat dilakukan dengan cara memindahkan produk yang sedang dirakit dari satu stasiun ke stasiun lainnya yang diikuti dengan berpindahnya para pekerja. Alasan untuk memindahkan produk yang sedang dirakit (tidak dilakukan perakitan pada satu stasiun saja) adalah karena banyaknya komponen yang harus dirakit dimana komponen tersebut harus diletakan di lebih dari satu stasiun. Perbedaan sistem perakitan ini dengan sistem perakitan konvensional adalah proses perakitan dilakukan oleh satu pekerja dalam tim yang ikut bergerak bersamaan dengan berpindahnya unit produk. Setiap pekerja dalam tim akan merasakan kepuasan pribadi yang lebih besar karena mengerjakan pekerjaan perakitan dalam porsi yang besar. Berbeda halnya dengan pekerja dalam lini perakitan konvensional dimana pekerja tersebut hanya melakukan porsi pekerjaan yang sangat kecil/sedikit, biasanya tidak memiliki tingkat kepuasan kerja yang tinggi. Keuntungan sistem perakitan ini dibandingkan sistem perakitan konvensional lainnya adalah kualitas produk yang lebih baik, naiknya tingkat kemampuan para pekerja dalam mengakomodasi variasi produk dan kemampuan menyelesaikan masalah yang lebih baik tanpa harus menghentikan proses produksi sama sekali. Dalam sistem perakitan ini laju kecepatan produksi akan ditentukan oleh kecepatan tim itu sendiri [1].

\section{METODE PENELITIAN}

Penelitian ini pada dasarnya berkaitan dengan proses desain ulang sebuah lini manufaktur konvensional menjadi sebuah lini manufaktur selular dengan tujuan utama untuk meningkatkan produktivitas tenaga kerja. Dimana untuk meningkatkan produktivitas tenaga kerja, ada banyak faktor yang perlu dipertimbangkan. Berbagai faktor itu saling berkaitan satu sama lainnya, sehingga mengubah satu faktor dapat memiliki dampak positif atau negatif terhadap faktor yang lainnya.

Penelitian ini dimulai dengan meneliti kondisi lini manufaktur konvensional diantaranya tentang aliran proses perakitan dan presedensinya, tata letak stasiun kerja, waktu siklus, kapasitas lini perakitan, produktivitas dan beberapa data-data lainnya termasuk ergonomi. 
Langkah selanjutnya adalah menganalisis setiap proses yang terjadi dalam lini perakitan konvensional. Dari hasil analisis ini ada beberapa tindakan yang diimplementasikan untuk perbaikan, seperti menghilangkan, mengurangi, menggabungkan dan membentuk grup perakitan selular. Setelah lini perakitan selular terbentuk dan diuji coba, maka data-data dari lini perkaitan ini akan dibandingkan dengan lini perakitan konvensional serta mengambil kesimpulan dan saransaran.

\section{HASIL DAN PEMBAHASAN}

Proses perakitan car stereo - mecha less ini terdiri dari 56 elemen kerja (EK) dengan perkiraan total waktu perakitan yang diperlukan sebesar 533 detik, dengan waktu siklus ideal (takt time) (TT) sebesar 38 detik per unit. Peta proses operasi dan diagram presedensinya dapat dilihat pada Gambar 1.
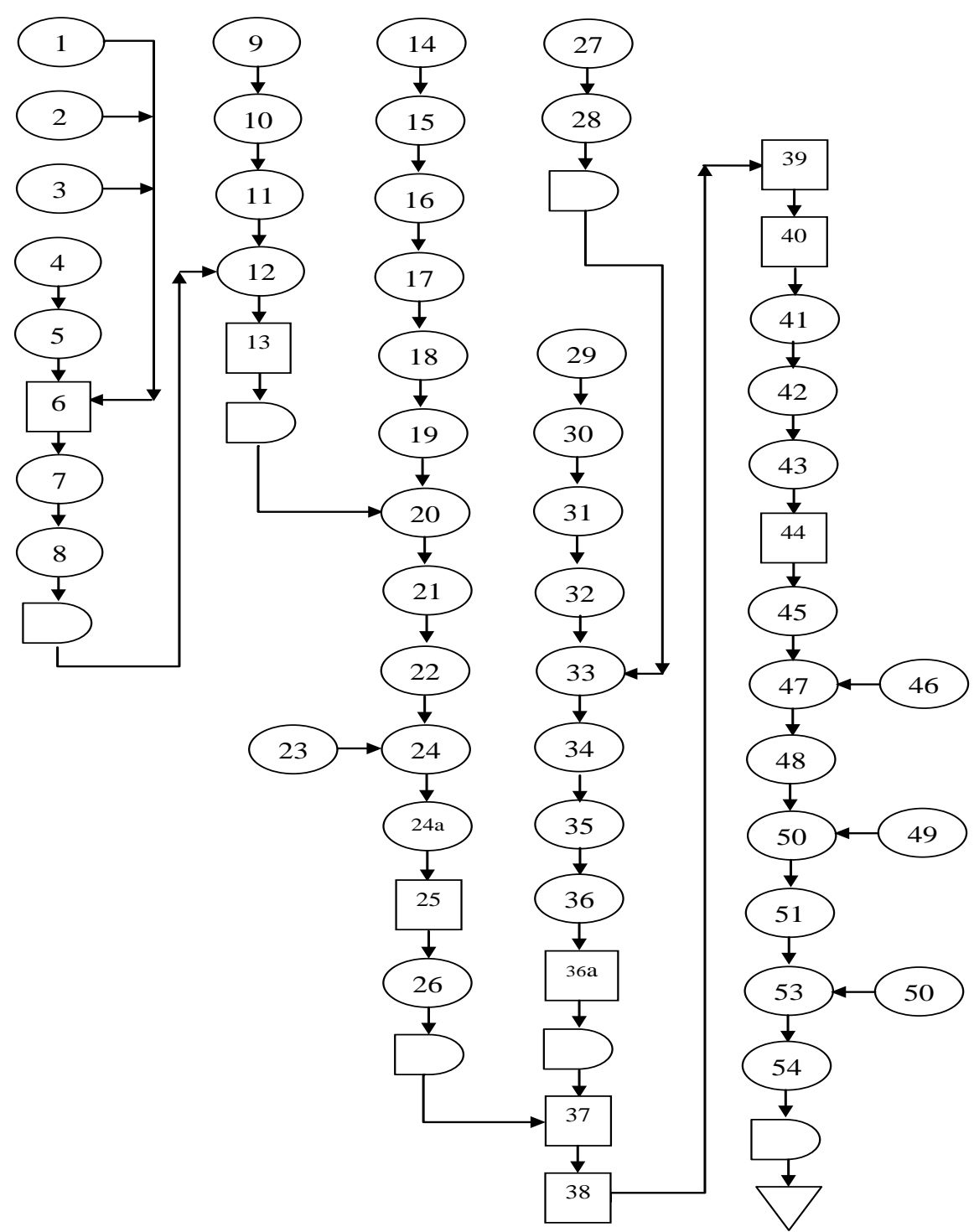

Gambar 1. Peta proses operasi dan presedensi perakitan

Pada lini konvensional, semua EK akan dikerjakan oleh 16 orang pekerja pada 16 stasiun kerja (SK). Dengan pembagian seperti ini, terdapat beberapa SK yang memiliki waktu kerja (WK) paling mendekati terhadap TT atau WK maksimal dan ada pula SK yang memiliki WK minimal dan jauh dibawah TT yang telah ditentukan. Keadaan ini dengan sendirinya akan menimbulkan idle pada SK yang memiliki WK rendah. Lini perakitannya dapat dilihat pada Gambar 2. 
Tanda panah pada Gambar 2 menunjukan arah aliran produk yang sedang dirakit, sedangkan setiap pekerja hanya berdiam/tidak berpindah pada posisi SK mereka masing-masing. Pada setiap SK, diijinkan terdapat work in process (WIP) atau sub-perakitan yang terhenti pada SK tersebut sebanyak maksimal 5 WIP, dan pada saat pengamatan WIP terbanyak terdapat pada SK1 hingga SK9 dengan jumlah WIP sebanyak 3 hingga 5 WIP. Adapun pada SK10 dan selanjutnya hampir tidak pernah ditemukan adanya WIP yang terhenti.

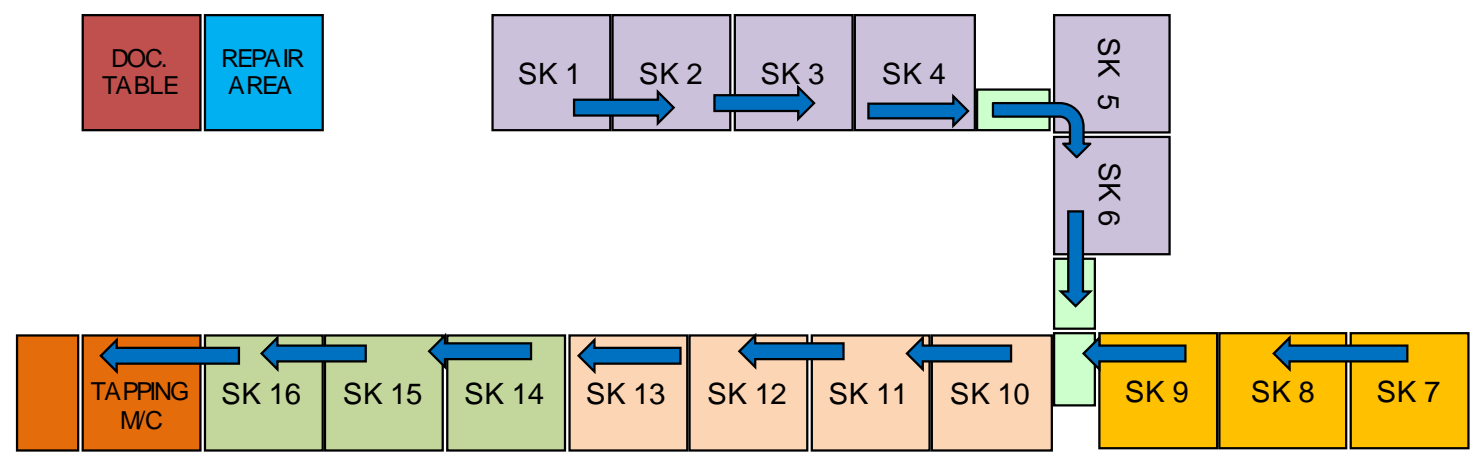

Gambar 2. Lini perakitan konvensional

Pembentukan lini perakitan selular dimulai dengan cara mengelompokan proses perakitan menjadi beberapa kelompok (sel kerja), menghitung jumlah pekerja yang diperlukan untuk setiap sel kerja yang dibentuk, memilih dan melatih ulang para pekerja yang akan ditempatkan pada sel kerja, menentukan gerak selular para pekerja dalam sel yang ergonomis, yakni dengan mengatur pergerakan setiap pekerja atau komponen agar tidak terlalu jauh dan atau saling bertabrakan.

Pengelompokan proses perakitan ini sebenarnya sudah dilakukan oleh perusahaan, terdiri dari 6 jenis kelompok perakitan. Akan tetapi jika mengikuti kelompok yang telah ditentukan tersebut, maka akan terdapat banyak sel yang harus dibentuk. Sehingga pengelompokan yang telah dibuat oleh perusahaan tidak akan digunakan dalam menentukan jumlah sel yang akan dibentuk.

Dengan mengacu pada pengelompokan yang sudah dibuat oleh perusahaan dan dengan mempertimbangkan kedekatan proses yang selama ini sudah berjalan, serta dengan menganalisis waktu siklus aktual pada lini konvensional, maka proses perakitan akan dibagi menjadi 4 (empat) sel, yaitu sel 1 terdiri dari EK1 hingga EK26, sel 2 terdiri dari EK27 hingga EK36a, sel 3 terdiri dari EK37 hingga EK40, dan sel 4 terdiri dari EK41 hingga EK54.

Penentuan jumlah pekerja dalam setiap sel kerja yang dibentuk dilakukan dengan cara menghitung jumlah stasiun kerja teoritis, yakni dengan cara membagi waktu total waktu kerja terhadap TT.

Satuan sel kerja yang dibentuk diharapkan agar tidak merubah ukuran stasiun kerja, sehingga stasiun kerja yang ada sekarang dapat dimanfaatkan tanpa harus melakukan modifikasi. Dengan tidak merubah ukuran stasiun kerja, maka diharapkan agar jumlah stasiun kerja sama dengan sebelumnya sehingga tidak diperlukan tambahan biaya atau biaya modifikasi peralatan dan stasiun kerja.

Selain benda kerja yang bergerak dari SK satu ke SK lainnya, pekerja pun akan diatur untuk bergerak dari satu SK ke SK lainnya. Dengan demikian maka pergerakan benda kerja dan pekerja diatur sedemikian rupa sehingga benda kerja akan mengalir tanpa ada hambatan dan pekerja bisa bergerak tanpa harus saling bertabrakan atau kelelahan bergerak / berpindah karena terlalu jauh. Pergerakan para pekerja antar SK kerja akan diatur hanya dengan satu langkah saja.

Untuk memudahkan pekerja bergerak dari suatu SK hingga kembali ke SK semula, maka sel kerja dibentuk dalam bentuk "U” dan atau "L" sehingga para pekerja dapat bergerak secara melingkar dan jarak yang ditempuh oleh para pekerja dari suatu SK ke SK lainnya hampir sama.

Kelompok perakitan dan sel kerja yang telah dibentuk di atas kemudian disatukan dalam suatu lini perakitan, hal ini agar aliran benda kerja bisa mengalir dari SK awal hingga SK akhir 
tanpa mengalami hambatan. Dan dengan demikian diharapkan juga agar jumlah work in process yang terjadi di lini perakitan dapat dihilangkan atau diperkecil.

Untuk menganalisa kedua lini perakitan, baik itu lini perakitan konvensional maupun lini perakitan selular, maka data-data pada kedua lini perakitan tersebut diambil atau diukur dan dibuat perbandingan. Data-data yang dapat diambil diantara adalah waktu stasiun kerja, tingkat cacat produk yang terjadi (Not Right First Time /NRFT), jumlah stasiun kerja, jumlah total pekerja dan nilai tambah setiap pekerja (Value Added Per Person / VAPP), serta luas lantai yang digunakan (Floor Space Utilisation / FSU). Adapun untuk efisiensi lini perakitan, produktivitas dan kapasitas lini perakitan dapat dihitung dari waktu stasiun kerja yang telah diukur, dimana data-data waktu kerja tersebut telah diuji kecukupan dan keseragaman datanya terlebih dahulu.

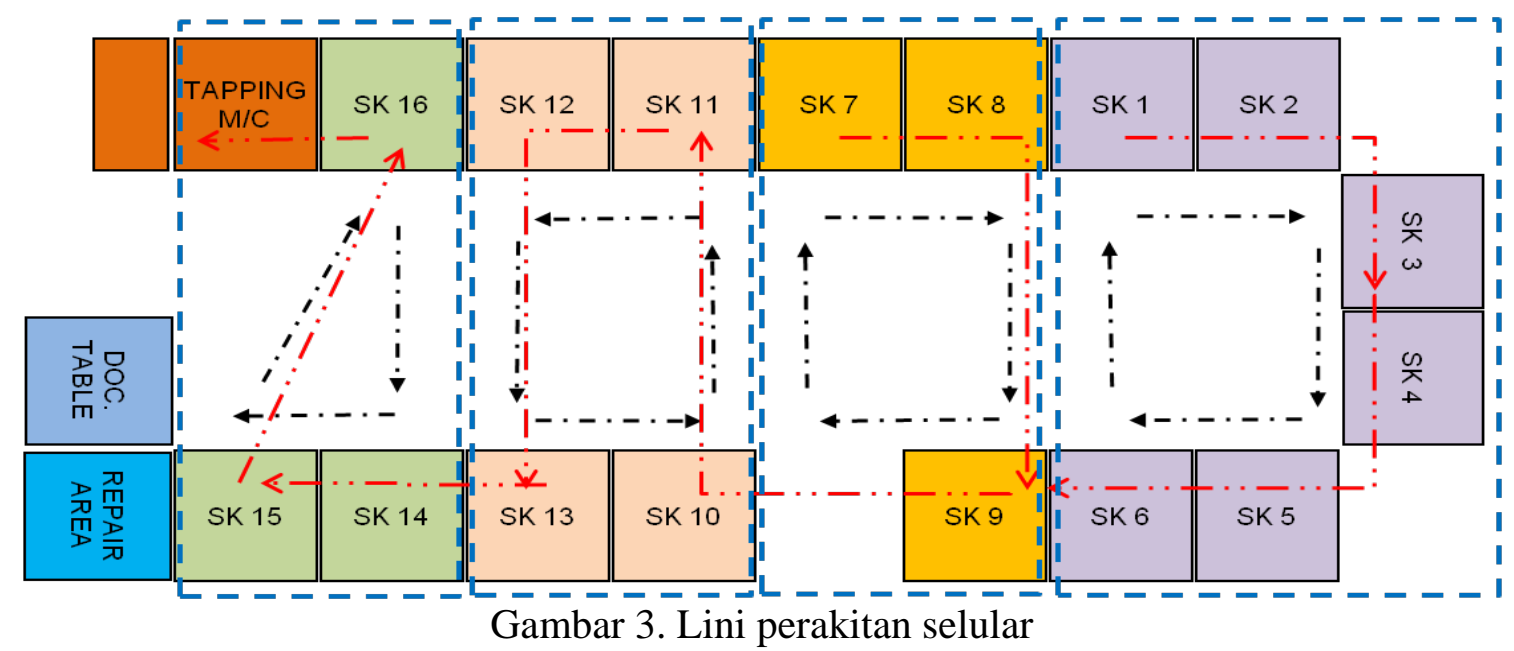

Keterangan gambar:

$$
\begin{aligned}
& -\square=-=\text { sel kerja } \\
& \text { - } \boldsymbol{-} \boldsymbol{>}=\text { jalur perpindahan pekerja } \\
& -\cdot-\boldsymbol{Z}=\text { jalur perpindahan benda kerja }
\end{aligned}
$$

\section{SIMPULAN}

Kesimpulan yang dapat diambil dari optimasi proses perakitan pada lini konvensional menjadi lini perakitan selular adalah sebagai berikut: tingkat pengetahuan para pekerja tentang proses perakitan car stereo dapat ditingkatkan menjadi 3 kali lipat hingga 6 kali lipat dari sebelumnya; jumlah pekerja dapat berkurang sebanyak 2 orang dengan jumlah stasiun kerja yang sama; efisiensi lini perakitan naik dari 89,23\% menjadi 95,64\% atau naik sebesar 7,18\%; produktivitas pekerja pada lini perakitan naik dari 72,88 unit per hari menjadi 83,29 unit per hari atau naik sebesar 14,28\% dengan kapasitas produksi yang sama; tingkat cacat produk yang ditemukan di lini perakitan (Not Right First Time/NRFT) mengalami penurunan dari sebesar 935,60 DPPM menjadi 584,75 DPPM atau turun sebesar 37,50\%; nilai tambah setiap pekerja (Value Added Per Person / VAPP) naik dari 0,063 $\$ X /$ pekerja menjadi 0,071 $\$ X /$ pekerja atau naik sebesar 12,70\%; utilisasi lantai produksi (Floor Space Utilisation / FSU) naik dari 0,063\$Y/m² menjadi $0,065 \$ Y / m^{2}$ atau naik sebesar $3,17 \%$.

\section{DAFTAR PUSTAKA}

[1]. Mikell P. Groover, 2002, Automation Production Systems, Prentice-Hall, New York.

[2]. D. Arun Kumar, V. Ramesh, 2012, Cellular Manufacturing Layout Design in Inner Tube Manufacturing Industry, International Journal of Scientific Engineering and Technology (IJSET), Volume 1, Issue 6.

[3]. R. Anthony Inman, 2013, Cellular Manufacturing. 
http://www.referenceforbusiness.com/management/Bun-Comp/Cellular-Manufacturing.html

[4]. Peetu Paul, Justin Koshy, Biju Cherian Abraham, 2013, Conversion of Regular Assembly Line into Cellular Manufacturing Layout, International of Journal of Engineering and Innovative Technology (IJEIT), Volume 2, Issue 7.

[5]. David C. Estrada, Abhinav Shukla, David S. Cochran, 2000, Converting from Moving Assembly Lines to Cells, The Third World Congress on Intelligent Manufacturing Processes \& Systems, Massachusetts Institute of Technology, Cambridge, MA 02139. 